\title{
Civil resistance in Public International Law
}

\author{
La resistencia civil en el Derecho Internacional Público
}

\author{
Dorothy EsTRADA TANCK \\ Assistant Professor of International Law \\ and International Relations \\ University of Murcia \\ dorothyestrada@um.es
}

RECIBIDO EL 5 DE OCTUBRE DE 2018/ ACEPTADO EL 11 DE ENERO DE 2019

\begin{abstract}
Civil resistance has rarely been analyzed from the field of public international law. This article will thus study the conception of civil resistance through its history and its current understanding in scholarship and practice, to then analyze its standing in public international law, considering doctrinal positions and the international legal framework. In this study it is argued that civil resistance may be grounded in international law general principles of law, and more concretely in the general principles of international human rights law. More particularly, it is submitted that international human rights law provides persons and organizations with a conceptual and at the same time operational basis to argue in favor of defending the rights of persons in conditions of vulnerability, discrimination, inequality and exclusion. The article will build on the legal framework and illustrative jurisprudence of United Nations, and regional human rights bodies, to reflect on its potential to serve as a foundation and a source of legitimation for civil resistance and people's movements in relation to human rights principles, values and norms.
\end{abstract}

Keywords: civil resistance, international law, human rights, vulnerability
Resumen: La resistencia civil se ha analizado en pocas ocasiones desde el ámbito del derecho internacional público. Por tanto, este estudio examinará la concepción de la resistencia civil a través de su historia y su comprensión actual, para luego analizar su naturaleza y posición en el ámbito del derecho internacional público, considerando las reflexiones doctrinales y el marco jurídico internacional. En el presente estudio se argumenta que la resistencia civil puede estar basada en los principios generales del derecho como fuente del derecho internacional público, y más concretamente en los principios generales del derecho internacional de los derechos humanos. Más particularmente, se afirma que el derecho internacional de los derechos humanos proporciona a las personas y organizaciones una base conceptual y al mismo tiempo operativa para defender los derechos de las personas en condiciones de vulnerabilidad, discriminación, desigualdad y exclusión. El artículo se basará en el marco jurídico y la jurisprudencia ilustrativa de los mecanismos de las Naciones Unidas, y los sistemas regionales de derechos humanos para reflexionar sobre su potencial como fundamento y fuente de legitimación de la resistencia civil y los movimientos populares en relación con los principios, valores y normas de los derechos humanos de las personas.

Palabras clave: resistencia civil, derecho internacional, derechos humanos, vulnerabilidad

Sumario: I. INTRODUCTION. II. CIVIL RESISTANCE FROM A HISTORICAL AND CONCEPTUAL PERSPECTIVE. A. Historical context. B. State-of-the art in the understanding of civil resistance. III. CIVIL RESISTANCE IN INTERNATIONAL LEGAL DOCTRINE AND NORMATIVE FRAMEWORK. A. Doctrinal context. B. International legal framework for civil resistance. 1. International human rights law. IV. PRACTICAL APPLICABILITY OF CIVIL RESISTANCE AND INTERNATIONAL HUMAN RIGHTS LAW: CONTEMPORARY CHALLENGES. A. Socio-economic precariousness. B. Undocumented migrants and other non-citizens. C. Gender inequality and violence against women. V. SOME CONCLUSIONS. 


\section{INTRODUCTION}

F

rom Thoreau's nineteenth century notion of civil disobedience as an act of individual willful resistance against laws considered to be hypocritical, to Gandhi and Hannah Arendt's emphasis on collective action, the civil rights movement in the United States, social mobilizations in Latin America, the antiapartheid movement, and nonviolent-led democratization in South East Asia and Eastern Europe,${ }^{1}$ civil resistance constitutes a touchstone for different issues highly relevant for public international law.

The importance of understanding civil resistance under an international law perspective is enhanced if one considers the increase of people's movements during our century. Indeed, after an earlier phase of activity in the late 1980s and early 1990s ended, the pace of this type of protests picked up again in 2005 and since then has reached a new peak. Since 2010, more than 60 countries -with all types of political regimes, including democracies- have experienced major protests. ${ }^{2}$ People's movements are occurring with growing frequency worldwide ${ }^{3}$ and the concept of civil resistance is currently being revisited as the foundation for protests, including in relation to human rights issues, for instance, in Spain. ${ }^{4}$

Today we know that nonviolent resistance holds proved efficacy as compared to violent struggles, ${ }^{5}$ a relevant fact if one considers that armed national liberation or independence movements have been considered to some extent within international law, ${ }^{6}$ while nonviolent movements less so.

Civil resistance and international law do, in fact, relate in different points. This study will focus on the source of general principles of law as the main foun-

1 For a full account, see Chenoweth, E.; STEPHAn, M.J. Why Civil Resistance Works: The Strategic Logic of Nonviolent Conflict, Columbia University Press, New York, 2011; and detailed geographical and academic data in the sources available from the International Center on Nonviolent Conflict, available at https://www.nonviolent-conflict.org/.

2 Just in 2015, significant protests took place in Armenia, Azerbaijan, Bosnia, Brazil, Burundi, the Democratic Republic of Congo, Guatemala, Iraq, Japan, Lebanon, Macedonia, Malaysia, Moldova, and Venezuela; see WILSON, E.A., People Power Movements and International Human Rights: Creating a Legal Framework, ICNC Monograph Series, August 2017, p. 10.

3 See Chenoweth, E.; Stephan, M.J., op. cit. and Carothers, T.; Youngs, R., The Complexities of Global Protests, Carnegie Endowment for International Peace, 2015, p. 3.

4 See, e.g., the issue of the journal Relaciones Internacionales, No. 39, 2018, Universidad Autónoma de Madrid, dedicated fully to the theme «Sobre la resistencia: Discusiones desde las Relaciones Internacionales».

5 See Chenoweth, E.; STEPhan, M.J., op. cit.

6 See, e.g., Longobardo, M. The Use of Armed Force in Occupied Territory, Cambridge University Press, 2018. 
dation for the legal framework covering people's movements. Let us note from the outset that civil resistance and international law find a common meeting point primarily in international human rights law. Indeed, human rights law has been constructed as part of a 'bottom-up' procedure and is the result, at least in part, of the struggle of grassroots movements and social mobilization and emancipation.?

Thus, the present study will use as a foundation the concept of civil resistance as a form of peaceful (non-armed) collective action directed at social change, in order to analyze the expression or reflection of such concept of civil resistance in international law. In section II, the conception of civil resistance will be studied from a historical perspective and its current understanding in scholarship and practice will be reviewed, to then analyze in section III its standing in public international law, considering doctrinal positions and the international legal framework mainly through general principles of law, and more concretely on the basis of general principles of international human rights law. In section IV, the text concentrates on putting the analytical framework to practice by spelling out specific situations to reflect on the current applicability of international human rights law in relation to people's movements confronting contemporary injustices, namely, socio-economic inequality; exclusion faced by undocumented migrants; and women experiencing gender inequality, and more specifically, women at risk of or suffering violence.

In doing so,this part specially reviews the ability of civil resistance and social movements to shape legal debate, values and norms, to the present in section $\mathrm{V}$ some conclusions on the empirical situations that might merit actions of civil resistance in contemporary reality and the legal framework that could justify them and serve as their basis for legitimation.

\section{CIVIL RESISTANCE FROM A HISTORICAL AND CONCEPTUAL PERSPECTIVE}

\section{A. Historical context}

Henry David Thoreau, referring particularly to the injustice of the US war against Mexico (1846-1848), described civil disobedience as an act of willful resistance, achieved by not obeying laws considered to be hypocritical. He was especially critical of the indifference of most people to the war and

7 See, e.g., Rajagopal, B., International Law from Below: Development, Social Movements and Third World Resistance, Cambridge University Press, 2003. 
other wrongs -such as slavery-, and as result, he deemed the resistance to civil government to be a moral and social duty of (American) citizens. In his classical 'Civil Disobedience' of 1849 he admitted that 'It is not a man's duty, as a matter of course, to devote himself to the eradication of any, even the most enormous, wrong; he may still properly have other concerns to engage him'; but warned that even when this is the case 'it is his duty, at least, to wash his hands of it, and, if he gives it no thought longer, not to give it practically his support', and more categorically added 'If I devote myself to other pursuits and contemplations, I must first see, at least, that I do not pursue them sitting upon another man's shoulders. I must get off him first, that he may pursue his contemplations too' ${ }^{8}$ That is,

[i] $f$ the injustice is part of the necessary friction of the machine of government, let it go, let it go: perchance it will wear smooth - certainly the machine will wear out. If the injustice has a spring, or a pulley, or a rope, or a crank, exclusively for itself, then perhaps you may consider whether the remedy will not be worse than the evil; but if it is of such a nature that it requires you to be the agent of injustice to another, then, I say, break the law. Let your life be a counter-friction to stop the machine. ${ }^{9}$

However, one can contrast Thoreau's more privileged and individualistic pursuit of personal integrity with Gandhi's focus on collective action. The latter's view was that civil disobedience should also be directed to impacting people and achieving strategic effectiveness-actually making social change, not just being personally pure. Also, Gandhi is the originator of the term 'civil resistance', which is a broader and more common term that is most often used in contemporary work in this field.

Trying to describe his nonviolent strategy for change, Gandhi rejected the Christian pacifist term 'non-resistance' and never much liked the more common term 'passive resistance'. Gandhi thought Thoreau's term 'civil disobedience' was better and more attractive, but was still dissatisfied. Gandhi ultimately adopted the term 'civil resistance' as the English translation for his term 'Satyagraha'. As he wrote in his letter to Shri P. Kodanda Rao, of the 'Servants of India Society', on 10 September 1935:

8 See Thoreau, H.D., «Civil Disobedience (1849)», in Civil Disobedience and Other Essays, Dover Publications, New York, 1993, particularly p. 6.

$9 \quad$ Ibid, p. 8. 
The resistance to authority in South Africa was well advanced before I got the essay of Thoreau on civil disobedience. But the movement was then known as passive resistance. As it was incomplete, I had coined the word satyagraha for the Gujarati readers. When I saw the title of Thoreau's great essay, I began the use of his phrase to explain our struggle to the English readers. But I found that even civil disobedience failed to convey the full meaning of the struggle. I therefore adopted the phrase civil resistance. ${ }^{10}$

Similarly, philosopher Hannah Arendt who developed her ideas in the context of post-World War II and the tragedy of the Holocaust, famously portrayed civil disobedience as group action which springs from common opinion rather than from common interest, and which should be directed outside the individual's subjective conscience to affect social change in cases of injustice. ${ }^{11}$

Other historical experiences come from the civil rights movement in the United States in the defense of black people's rights and racial equality -think of the action of Martin Luther King or Rosa Parks-, ${ }^{12}$ the social protests and mobilization in Latin America against socio-economic injustice and often in favour of indigenous rights, ${ }^{13}$ the antiapartheid movement, and nonviolent-led democratization in South East Asia and Eastern Europe. ${ }^{14}$

10 Weber, T. Gandhi as Disciple and Mentor, Cambridge University Press, 2004, p. 44. I thank Stephen Chase from the International Center on Nonviolent Conflict for directing me to this perspective of Gandhi as compared to Thoreau.

11 See the classical work by Hannah Arendt in «Civil disobedience», in Crises of the Republic, Penguin Books, 1973, in particular p. 43. For a critique of Arendt's view of civil disobedience as a predominantly Western endeavor, see KALA, S., «Hannah Arendt on Civil Disobedience», in Indian Philosophical Quarterly, vol. X11, n. ${ }^{\circ} 3$ and 4, July-September and October-December 1986, pp. 261-269.

12 See, e.g., McGuire, D.L., At the Dark End of the Street: Black Women, Rape, and Resistance - A New History of the Civil Rights Movement from Rosa Parks to the Rise of Black Power, Vintage Book, USA, 2011.

13 See, e.g. Rivera Maldonado, A. La resistencia a la opresión. Un derecho fundamental, Facultad de Derecho de la Universidad Autónoma de San Luis PotosíComisión Estatal de Derechos Humanos de San Luis Potosí, Centro de Estudios Jurídicos y Sociales P. Enrique Gutiérrez, San Luis Potosí/ Aguascalientes, 2009. Social protest in Latin America portrays a collective character and has been strongly tied to the struggle for socio-economic justice in circumstances marked by severe poverty, inequality, and often violence. Some movements are also tied to the fight for the rights of indigenous peoples, the recognition of their right to self-determination, their cultural identity and their forms of social, economic and political organization, as well as the admission by the State of legal pluralism where indigenous customary norms are accepted as valid sources of law. See also ALVARADO CHÁvEZ, M., «Indignarnos y ejercer nuestro derecho a la resistencia: Resistencia y rebeldía no son lo mismo pero sí cercanas», El Periódico, Guatemala, 14 January 2019, available at https:// elperiodico.com.gt/opinion/2019/01/12/indignarnos-y-ejercer-nuestro-derecho-a-la-resistencia/

14 For a full account, see Chenoweth, E.; STEPhan, M.J., Why Civil Resistance Works: The Strategic Logic of Nonviolent Conflict, Columbia University Press, New York, 2011; and detailed geo- 
The intellectual founder of the academic study of civil resistance is usually considered Gene Sharp. Having carried out research on several cases, from the Indian independence movement to labor struggles and varied situations around the world, Sharp aimed at examining nonviolent movements as a social science, leaving aside ethical or religious insights and performing a comparative study in order to reach theoretical conclusions on the dynamics which underpin nonviolent struggle. ${ }^{15}$

Today's generalized view is that civil resistance involves nonviolent modes of expression, mobilization and protest that should be directed to impacting people effectively, that is, to actually influence society and not only to act according to one's own individual and personal conscience.

As we will see, the dominant scholarship, however, does not fully address the question of whether international law may provide useful tools to help construct, justify, or enhance civil resistance as a form of collective action seeking to express dissent with majority rule and opposition to laws or policies that are deemed to be fundamentally unjust, which will thus be the central focus of this study.

\section{B. State-of-the art in the understanding of civil resistance}

The detailed comparative work by Erica Chenoweth and Maria J. Stephan, Why Civil Resistance Works: The Strategic Logic of Nonviolent Conflict, has been pivotal to advance understanding of the effectiveness of non-violent movements as compared to violent forms of resistance. ${ }^{16}$ Robert $M$. Press has analysed civil resistance as a form of furthering human rights and gaining or reaffirming democracy, ${ }^{17}$ and Véronique Dudouet and Howard Clark, in 'Nonviolent Civic Action in Support of Human Rights and Democracy', ${ }^{18}$ underline the necessity of international support of civic action

graphical and academic data in the sources available from the International Center on Nonviolent Conflict, available at https://www.nonviolent-conflict.org/.

15 SHARP, G. The Politics of Nonviolent Action. Boston, Porter Sargent, 1973.

16 Chenoweth, E.; Stephan, M.J., op. cit.

17 Press, R.M., Peaceful Resistance: Advancing Human Rights and Democratic Freedoms, Ashgate, Burlington, 2006.

18 Dudouet, V.; Clark, H., «Nonviolent Civic Action in Support of Human Rights and Democracy», published by the Directorate-General for External Policies, European Parliament, 2009, available at http://www.nonviolent-conflict.org/images/stories/pdfs/est25679.pdf 
at the local level to be anchored in grass-roots movements and not move away from their strategies and goals. The work $A$ Guide to Civil Resistance of the International Center on Nonviolent Conflict (ICNC) is an extremely useful orienting source on the substantive matters addressed in civil resistance movements throughout history and different geographies and political contexts. ${ }^{19}$

In the realm of political theory (though influential in legal scholarship), a 'right to democracy' was articulated in 2001 by John Rawls in The Law of Peoples, in which he argued for a distinction between human rights and democracy. Under the aim of attempting to reach consensus about basic human rights, Rawls submitted that 'decent' (though non-democratic) States were able to respect human rights. In his view, the international community can only require a State to actually protect human rights, not to do so in the form of a concrete system of governance such as a democratic regime..$^{20} \mathrm{~A}$ right to democracy would seem to serve as foundation for civil resistance, although its condition as an authentic 'right' in the legal sense remains debated, ${ }^{21}$ as we will review in the following section of this study.

Given that most of this scholarship stems from a political perspective, this study aims at complementing existing work by examining primarily from a legal lens, the presence of civil resistance in international law (mainly international human rights law), the actions by civil society actors before international human rights bodies and mechanisms, and their responses to what could be termed civil resistance challenges.

As referred to above, international human rights legal scholars and practitioners hold good motives to give nonviolent civil resistance increased attention. People's movements are occurring with growing frequency worldwide..$^{22}$ In this context, the potentials of using international human rights law as a basis for civil resistance, thus strengthening and legitimizing people's movements, has rarely been explored. Notable exceptions include Matthew Lippman's

19 See particularly CHAPTER F., «Feminist Movements and Protests», in vol. 2, available at https:// civilresistance.info/bibliography. See also regarding the struggle for women's rights, BEYERLE, S., «Courage, Creativity, and Capacity in Iran: Mobilizing for Women's Rights and Gender Equality», in Georgetown fournal of International Affairs 9, 2008, pp. 41-49.

20 RaWLs, J., «The Law of Peoples», in Critical Inquiry, vol. 20, No. 1, Autumn, 1993, pp. 36-68.

21 See, e.g., Lister, M., «There is no Human Right to Democracy. But May We Promote It Anyway?», in Stanford fournal of International Law 48, 2012.

22 See Chenoweth, E.; Stephan, M.J., op. cit. and Carothers, T.; Youngs, R., The Complexities of Global Protests, Carnegie Endowment for International Peace, 2015, p. 3. 
'The Right of Civil Resistance Under International Law and the Domestic Necessity Defense', ${ }^{23}$ 'International human rights law and social movements: States' resistance and civil society's insistence', by Kiyoteru Tsutsui, Claire Whitlinger, and Alwyn Lim, ${ }^{24}$ and more recently, the wide-ranging work by Elizabeth A. Wilson, People Power Movements and International Human Rights: Creating a Legal Framework. ${ }^{25}$

It is also worth noting that few publications refer to civil resistance and international human rights law in recent Mexican and Latin American experience, and rarely include the views and voices of Latin American scholars and activists themselves, particularly those who only write and publish in Spanish. In this sense, the analysis of civil disobedience in the field of asylum law, ${ }^{26}$ or 'civil disobedience as a human right' as formulated in Mexico, ${ }^{27}$ remain fascinating roads to explore in future research in this area.

\section{CIVIL RESISTANCE IN INTERNATIONAL LEGAL DOCTRINE AND NORMATIVE FRAMEWORK}

\section{A. Doctrinal context}

While civil resistance to autocratic governments has been analyzed at length, as well as the 'right to resistance' or 'ius resistendi', in different constitutional regimes, ${ }^{28}$ questions remain as to the legitimacy to exercise this right within a liberal constitutional democracy. Apart from the natural choice of

23 Lippmann, M., «The Right of Civil Resistance Under International Law and the Domestic Necessity Defense», in Penn State International Law Review, vol. 8, No. 3, Article 2, 1990, pp. 349373.

24 In Annual Review of Law and Social Science, vol.8, 2012, pp. 367-396.

25 WiLson, E.A., People Power Movements and International Human Rights: Creating a Legal Framework, ICNC Monograph Series, August 2017.

26 Falcón y Tella, M.J., «Desobediencia civil y derecho de asilo», in Revista Hispano-Cubana, No. 6, 2000, pp. 157-162.

27 Ramírez BaENA, R., «La desobediencia civil como derecho humano», in 4 Vientos. Periodismo en Red, 3 September 2013, available at http://www.4vientos.net/2013/09/03/la-desobediencia-civil-como-derecho-humano/ (last accessed 5 September 2018).

28 Ugartemendia ECEIZABarRena, J.I., «El derecho de resistencia y su 'Constitucionalización'», en Revista de Estudios Políticos (Nueva Época), n. ${ }^{\circ}$ 103, enero-marzo 1999, pp. 213-245; GUTIÉRREZ GONZÁLEZ, C.M., «El control constitucional de las leyes y el derecho a resistir el Derecho» (Documento de Trabajo), Universidad Latina de América, 2017. 
examining this dilemma from the view of political theory as recounted above, the subject has also been examined from the perspective of constitutional law. As such, a right to 'constitutional resistance' has been articulated as a form of carrying out actions of opposition within the framework of the democratic Constitutional legal order with the aim of realizing the values and spirit contained in the Constitution when current political power has betrayed or derailed them. ${ }^{29}$ One possible avenue for thought in this terrain is whether international (human rights) law may serve as a parameter of reference and a legal source for framing and legitimizing civil resistance movements, including in Constitutional democracies.

Since the central focus of this study is civil resistance under public international law, let us analyze the topic from the perspective of the sources of public international law on the basis of article 38 of the Statute of the International Court of Justice (ICJ) -international treaties, international custom, and general principles of law- as primary sources according to article 38; and jurisprudence and doctrine as subsidiary sources of international law.

In studying civil resistance and people's movements in international law, Elizabeth A. Wilson has developed an analytical framework particularly on the foundation of article 38.1,c) of the ICJ Statute, 'general principles of law', specifically as related to human rights law. She has identified four general principles that structure the human rights project: non-exploitation, non-discrimination, non-repression and non-violence. These 'general principles', as she explains, crosscut four dimensions of law (international and domestic law, positive and natural law) and comprise a human rights ethos. Using a typology derived from these four principles, nonviolent civil resistance movements may be critically examined for how fully they manifest this human rights ethos..$^{30}$

Indeed, a human rights ethos is to be found at the core of the international legal system (among other legal systems, as Wilson notes). The respect, protection and fulfilment of universal human rights are core values of the international community and a universal obligation at the basis of the whole international legal order, as contained in articles 1, 55 and 56 of the United Nations (UN) Charter. On this basis, the Universal Declaration of Human

\footnotetext{
29 See, e.g., ViTALE, E., Defenderse del poder: Por una resistencia constitucional (trad. P. Salazar Ugarte y P. S. Vásquez Sánchez), Madrid, Trotta, 2012; in a similar sense, see UGARTEMENDIA, op. cit., pp. 231 and 244.

30 WILSON, E.A., op. cit.
} 
Rights (UDHR) was adopted in 1948, and is also considered today as international customary law. ${ }^{31}$ The two main international Covenants -on Civil and Political Rights (ICCPR) and on Economic, Social and Cultural Rights (ICESCR)-, adopted in 1966 as a development of the UDHR, reflect basic human entitlements crafted as legally binding human rights and containing concrete State obligations. The so-called 'International Bill of Human Rights' (formed by the UDHR and the two Covenants) has functioned as the basis for the legal articulation of specific human rights treaties in the last 70 years.

This gives rise to reflection on the legal foundation for civil resistance from the perspective of the sources of international law. Through this lens, civil resistance may be based on general human rights principles and at the same time on concrete human rights norms.

Let us recall, as Cesáreo Gutiérrez Espada and María José Cervell explain, that 'if the principles embody the fundamental values of the [international] order, the norms establish more concrete rules, which regulate the diversity and plurality of situations that occur between the members of the social group'. ${ }^{32}$ In this sense, the articulation of civil resistance may be grounded in general principles of law, concretely in general human rights principles, insofar as it such people movements align with what Wilson terms 'the human rights ethos', a centripetal point of reference for the essential values of the international community.

At the same time, civil resistance also finds a foundation in international norms in the sense referred to, since its exercise is based on specific rules that allow or mandate certain behaviors in particular situations. These norms are of a conventional character given they are contemplated in diverse legal dispositions of concrete international treaties, as will be seen in the following section. As an issue for future study, the case might be made that such norms also hold a customary nature, since a right to resistance is reflected in the Constitutions and in the practice of some States.

In any case, the perspective of civil resistance as grounded in general human rights principles of law and in international legal norms is confirmed by observing that some of the values justifying civil resistance, that is, the struggle for equality before the law and the defense of human dignity, have

31 See, e.g., KaczorowsKa, Alina, Public International Law, 5th edn, Oxon and New York, Routledge, 2015; and Schachter, Oscar, International Law in Theory and Practice, The Netherlands, Martinus Nijhoff Publishers, 1991, pp. 35-38.

32 Gutiérrez Espada. C.; Cervell Hortal, M.J. El derecho internacional en la encrucijada (fourth edition, Trotta, España 2017), p. 33. Translation from Spanish to English of this autor. 
been considered as a principle and as a right in many national jurisdictions, as well as at the level of the European Union, to give but another example. ${ }^{33}$ All of the above added to the examination in this study of the jurisprudence of the UN system and regional human rights systems, allows to conclude that in public international law civil resistance is enabled by legal norms of concrete international treaties, as well as through general principles that transversally permeate the interpretation of the international legal system.

\section{B. International legal framework for civil resistance}

International law, although State-centric in essence, has recognized to a certain extent the idea of civil resistance. It arises in at least three different realms of international law: 1) the law pertaining to the UN Charter, where issues of non-intervention in the internal affairs of a State are addressed; 2) international humanitarian law which regulates the conduct of armed conflicts and protection of unarmed civilians; and 3) international human rights law, which is much broader in its application as it regulates situations of peace and war and includes norms directly relevant to one of civil resistance's cornerstone rights - the right to peaceful assembly.

Following existing scholarship, reviewed herein, revealing that the strongest intersection of civil resistance to international law is through international human rights law, the present study will center mainly on this last branch of law as the sphere of international law most relevant to nonviolent movements, although more general points of international law are touched upon as well.

Concerning the first area of general public international law under the UN Charter, civil resistance may find a foundation when it demands democratic rule and the right to self-determination of peoples (covered indirectly by the UN Charter through the link of article 1 to article 55 of the Charter and the development of article 1 of the ICCPR and the ICESCR enclosing the right to self-determination of peoples). However, the existence of a 'right to democracy' in international law as proposed in the post-Soviet Union era at the beginning of the 1990s, remains a debated issue given that the idea that the

33 See, e.g., Hernu, R. Principe d'égalité et principe de non-discrimination dans la jurisprudence de la Cour de justice des communautés européennes, L.G.D.J., Paris, 2003; and LANG, R. Complex equality and the Court of fustice of the European Union: reconciling diversity and harmonization, Brill, Boston, 2018. 
international community can impose the standards on which the democratic entitlement is based is in tension with the principle of State sovereignty, embodied in Article 2.7 of the UN Charter, which provides that the UN shall not interfere in matters 'essentially within the domestic jurisdiction of States'. ${ }^{34}$ The possibility of circumventing such prohibition in cases of genocide, crimes against humanity or grave human rights violations has been studied elsewhere through the topic of humanitarian intervention or other proposals such as the responsibility to protect, which exceed the scope of this study. In any case, suffice it to say that there are other more recent views that propose that a right to democracy can be triggered in the context of a nonviolent movement engaged in a self-determination struggle, irrespective of whether there is a general right to democracy recognized in international law, provided that it meets the criteria set forth by general human rights principles. ${ }^{35}$

As to the second field of international humanitarian law, a brief mention is in line regarding how resistance to military occupation has been particularly addressed. After the experience of the Second World War, in which resistance to German occupation had been widely viewed as legitimate by European States, a change was introduced in the first three 1949 Geneva Conventions on the normative framework applicable to armed conflict. ${ }^{36}$ The modification consisted in the enhancement of the category of those entitled to prisoner of war status to include 'Members of other militias and members of other volunteer corps, including those of organized resistance movements, belonging to a Party to the conflict and operating in or outside their own territory, even if this territory is occupied'. ${ }^{37}$ As has been noted, the most important innovation was the explicit recognition that such resistance movements could operate 'in or outside their

34 See Franck, T.M., «The Emerging Right to Democratic Governance», American fournal of International Law 86, 1992, pp. 47-48.

35 For a detailed account of this idea proposed by Elizabeth A. Wilson, see Wilson, E.A., op. cit., p. 122.

36 RoBerts, A., «Resistance to Military Occupation: An Enduring Problem in International Law», American fournal of International Law, vol. 111, 2017, p. 46. In this same sense, see the account by CASSESE, A., International Law, 2nd edn, Oxford University Press, Oxford, 2005, p. 402.

37 Geneva Convention relative to the Treatment of Prisoners of War art. 4A(2), Aug. 12, 1949. See also the First Geneva Convention, Article 13, and the Second Geneva Convention, Article 13. A related issue under debate, in this case concerning armed movements, has been the reflection on the position by the ICJ in its Advisory Opinion Legal Consequences of the Construction of a Wall in the Occupied Palestinian Territory (2004) regarding the illegality of self-defense in relation to armed groups under occupied territory, in LONGOBARDO, M., «The self-proclaimed statehood of the Islamic State between 2014 and 2017 and International Law», in Anuario Español de Derecho Internacional, vol. 33, 2017, at p. 207. 
own territory, even if this territory is occupied» (art. 1 of the Hague Regulations of 1899 and 1907 had not specified its applicability to occupied areas.) ${ }^{38} \mathrm{~A}$ limitation of this 1949 provision is that it does not cover certain movements and types of activity that have been recurring features of many occupations, e.g., civil resistance employing nonviolent forms of action (e.g. strikes, demonstrations, and disobedience of specific orders of the occupant). ${ }^{39}$

In any event, the reviewed provisions come to illustrate the shift in the views on the meaning and scope of sovereignty in international law. For some authors, in modern international law, we see how 'State sovereignty remains an important pillar in the structure of international law, but the notion that sovereignty resides in the head of state gave way long ago to recognition that it rests in a nation's people'. ${ }^{40}$ As such, the range of sovereignty became more specific in the twentieth century and was constructed as a broad normative corpus created to protect internationally recognized human rights. However, the current international legal system still remains primarily and formally a State-centric one, with States as the only recognized law-makers, including in matters of human rights.

What is a generally observable fact is that indeed, the rule of law, democratic governance and internationally recognized human rights have become the common language, the source of legitimacy for domestic and international action, and the axis for modern political engagement and the furthering of social change - to follow such concepts and values is to be 'on the right side of the law'. ${ }^{41}$ As set forth above, on the basis of international law, the nature of a State's government is an internal issue, though as a practical matter, 'it makes a difference whether a state is democratic or undemocratic, welfarist or not, isolationist or interventionist, as its actions affect the formation of future conventional and customary international law'. ${ }^{42}$

38 Roberts, A., op. cit.

39 It must be noted, though, that persons engaging in at least some of these activities were not left entirely outside the radar of the 1949 Geneva Conventions. Certain rights of the Fourth Convention on civilians, were set forth for spies and saboteurs in occupied territory (art. 5), dealt with transfers of population (art. 49), and contemplated penal provisions for protected persons acting against the occupant (art. 68).

40 ROBERTS, A., op. cit.

41 Glennon, M.J.; Ackermann, P., «The Right Side of the Law», in The American Interest, vol. 3, N. 1, September 1, 2007, available at https://www.the-american-interest.com/2007/09/01/theright-side-of-the-law/

42 Wilson, op. cit., p. 11, and Chenoweth, E.; Stephan, M.J., «How the World is Proving Martin Luther King Right about Nonviolence», Washington Post: Monkey Cage (blog), January 18, 2016, available at https://www.washingtonpost.com/news/monkey-cage/wp/2016/01/18/howthe-world-is-proving-mlk-right-about-nonviolence/. 
As has also been noted, even when the formal law-making process has been followed by States, human rights law has been constructed partly as the result of a bottom-up process with a strong participation of people's movements around the world. Thus, in this section the status of civil resistance is explored, primarily in international human rights law as the general branch of law providing the building blocks for the articulation of a legal framework on the matter.

\section{International human rights law}

Different issues come to mind when addressing the relation of civil resistance to international human rights law. One might think firstly of conscientious objection as part of the recognition of the right to freedom of conscience ${ }^{43}$ although this falls more within the realm of individual belief and not of collective social action as addressed by civil resistance. Directly concerning people's movements, the international legal community is beginning to consider civil resistance, mainly to the extent of defining the range of a right to peaceful protest. Also, and in a similar reflection to that conveyed in the context of Constitutional democracies, from an international human rights law perspective a 'human right to resist' has also been proposed, ${ }^{44}$ though not yet fully developed.

Let us also recall that at the level of national laws, some constitutions have elevated to constitutional level the right to resistance. ${ }^{45}$ To give but a recent example, consider the 2008 Constitution of Ecuador, which is one of

43 See, e.g., LEIGH, I., «The legal recognition of freedom of conscience as conscientious objection: familiar problems and new lessons», in AHDAR, R. (ed.), Research Handbook on Law and Religion, Edward Elgar Publishing, 2018, pp. 378-396, who notes that through the progressive recognition of the right of conscientious objection to military service, international tribunals have dealt with questions regarding the treatment of beliefs about the sanctity of life and of countervailing societal interests. He also emphasizes that by contrast, the recognition of conscience of medical personnel relating to healthcare decisions, such as provision of abortion or contraception, is at an earlier stage of development, with a number of important unresolved questions. These concern whether conscience is better protected as a freestanding right or a subset of religion and belief, questions of complicity and the proximity of conscience and action, whether the right is absolute or limited, and whether public or professional duty and conscience are mutually exclusive.

44 Bartkowski, M.; Bellal, A., «A Human Right to Resist», openDemocracy (May 3, 2011), available at https://www.opendemocracy.net/maciej-bartkowski-annyssa-bellal/human-rightto-resist (last accessed 5 September 2018).

45 See, e.g., Rivera Maldonado, A., op. cit. 
the most advanced legal texts concerning progressive and emerging human rights, its view of gender equality and equal distribution of public and private power, including the roles of care, and -as analyzed elsewhere- its inclusion of human security provisions. ${ }^{46}$ In a similar line, the Constitution includes in article 98 what has been termed the 'right to resistance' by setting forth that 'Individuals and groups may exercise the right to resist against actions or omissions of public power or of natural or legal non-state actors, which violate or may violate their constitutional rights, and demand the recognition of new rights'. As submitted above, the case might be made that the norms on civil resistance also hold a customary nature in international law, given the fact that a right to resistance is reflected in the Constitutions and in the practice of some States.

Considering Elizabeth A. Wilson's categorization analyzed above, and viewing civil resistance as grounded in general human rights principles and norms, let us review the specific human rights provisions and interpretations that reflect civil resistance concerns or enable its exercise.

Though the right to protest is not enclosed per se in the 'International Bill of Rights' formed by the UDHR and the two Covenants (ICCPR and ICESCR), nonetheless it can be derived from the right to freedom of opinion and expression which 'includes the freedom to hold opinions without interference and to seek, receive and impart information and ideas through any media and regardless of frontiers' (art. 19 UDHR, art. 19 ICCPR) and the right to peaceful assembly (art. 20 UDHR, art. 21 ICCPR).

On the other hand, Article 1 in both Covenants, covering the right to self-determination, seems to guarantee the right of a people to democratically choose their form of self-government, although there is still debate about whether there truly exists a 'right to democracy' under international human rights law. ${ }^{47}$ In any case, Article 25 of the ICCPR protects, among other things, the rights 'to take part in the conduct of public affairs, directly or through freely chosen representatives' and 'to vote and to be elected at genuine periodic elections which shall be by universal and equal suffrage and shall be held by secret ballot, guaranteeing the free expression of the will of the electors'.

\footnotetext{
46 See Estrada Tanck, D.. Human Security and Human Rights under International Law. The Protections Offered to persons Confronting Structural Vulnerability, Hart Publishing, Oxford, 2016.

47 See, e.g., WILSON, op. cit., pp. 122-123.
} 
At the regional level, the right to freedom of opinion and expression as well as the right to peaceful assembly are also protected in instruments such as the European Convention on Human Rights (ECoHR), the American Convention on Human Rights (ACHR) and the African Charter on Human and Peoples' Rights (ACHPR). We may thus conclude that the right to peaceful protest, derived from interlinked and relevant legal norms, can be said to be protected and safeguarded by international law and can consequently be enforced through a judicial body as well as through quasi-judicial bodies, such as the UN Human Rights Committee.

In fact, in interpreting the ICCPR, the UN Human Rights Committee, in its General Comment 34, recognized the relevance of institutional mechanisms to enable society action as an essential element to comply with the Covenant: 'To give effect to the right of access to information, States parties should proactively put in the public domain Government information of public interest... States parties should also enact the necessary procedures, whereby one may gain access to information, such as by means of freedom of information legislation'. ${ }^{48}$

At a more particular stance, there are also other judicial and quasi-judicial paradigmatic cases which serve to exemplify the response by international human rights law, at the $\mathrm{UN}$ and regional levels, as related to civil resistance concerns.

Let us then review the analytical points explained herein and their applicability at a practical level. Some of the issues that portray the most pressing questions for contemporary justice and international law will be reviewed. We will examine if and how they may be challenged through actions of civil resistance and the response international human rights mechanisms have conveyed so far in the face of such challenges.

\section{PRACTICAL APPLICABILITY OF CIVIL RESISTANCE AND INTERNATIONAL HUMAN RIGHTS LAW: CONTEMPORARY CHALLENGES}

Already in the late 1990s, international legal scholars recognized that for activists 'the constructive role of international law in the post-Cold War era will be greatly enhanced if nongovernmental organizations seek self-consciously to

48 UN Human Rights Committee, General Comment 34, U.N. Doc. CCPR/C/GC/34, para. 19. 
participate in, influence, and ultimately enforce transnational legal process by promoting the internalization of international norms into domestic law' ${ }^{49}$

Let us recall that civil resisters use a wide range of tactics, some of which may be visible or invisible, high risk or low risk, and economic, political, or social in nature. These tactics often include marches, demonstrations, strikes, various forms of noncooperation, boycotts, civil disobedience, and constructive actions, such as building parallel social, economic, cultural, or political institutions as an alternative to the existing repressive structures. ${ }^{50}$

Regarding this last type of activity, one may find illuminating cases that also include the proposal of parallel legal 'institutions'. Consider the case of people who performed as 'operators' of the traditional positive law system and also contributed (at the same time or in different periods of their lives) to the development of alternative legal and judicial bodies. To give but one example, think of the case of Judge Françoise Tulkens, former Judge and Vice-President of the European Court of Human Rights, who participated in 2016 as Chair of the 'International Monsanto Tribunal' in The Hague, a civil society initiative with educational and public awareness goals, created to give a voice to witnesses of this transnational corporation's alleged environmentally-harming activities, to enable the public to understand the impacts of Monsanto's actions, and to help advance international law by offering or studying new ideas such as the concept of 'ecocide' or the responsibilities of business regarding human rights. ${ }^{51}$

49 Koн, H.H., «Why Do Nations Obey International Law?», in Yale Law fournal, 106, 1997, p. 2657. See also in a similar line, GEER, M.A., «Human Rights and Wrongs in Our Own Backyard: Incorporating International Human Rights Protections Under Domestic Civil Rights Law: A Case Study of Women in United States Prisons», in 13 Harvard Human Rights Fournal, 2000, pp. 71-140; and Risse, T.; SIKKINK, K., The Power of Human Rights: International Norms and Domestic Change, Cambridge, Cambridge University Press, 1999.

50 BartKowski, M.; Merriman, H., «Civil Resistance», in Oxford Bibliographies, 2016, available at http://www.oxfordbibliographies.com/view/document/obo-9780199743292/obo-97801997432920194.xml (last accessed 10 September 2018).

51 See Barroux, R., «Quel est le contexte juridique du vrai-faux «procès» de Monsanto?», in Le Monde, 16 October 2016, available at http://www.lemonde.fr/planete/article/2016/10/16/ nous-allons-verifier-si-les-activites-de-monsanto-sont-en-conformite-avec-les-regles-dedroit_5014553_3244.html On Judge Tulkens' more general contributions to international and European human rights law, see RINGELHEIM, J., «The art of dissenting. A few words on Judge Tulkens' legacy», in The Strasbourg Observers, August 22, 2012, available at https://strasbourgobservers.com/2012/08/22/the-art-of-dissenting-a-few-words-on-judge-tulkens-legacy/ (both entries last accessed 5 September 2018). On people's tribunals, see also more generally 'Peoples' tribunals and international law', at Australian Human Rights Centre, UNSW Sydney, available at http://archive.ahrcentre.org/topics/peoples\%E2\% 80\%99-tribunals-and-international-law (last accessed 6 September 2018). 
In the social lived experience, civil resistance actions have been directed at Campaigns for Social and Economic Justice, Indigenous Movements, Green Campaigns and Protests, Peace Movements, Resistance Movements Against Specific Wars, Feminist Movements and Protests, Campaigns for Gay, Lesbian and Transgender Rights, Campaigns Against Government, Regional Campaigns for Civic, Cultural or National Rights, Struggles for Racial Justice, and Preparation and Training for Nonviolent Action. ${ }^{52}$ To this list one could add recent movements not only searching the recognition, fulfillment or enhancement of certain rights, but also protests directed at drawing 'red lines' in order not to lose rights that have already been gained in the legal and political arena.

Indeed, social movements and organized civil society action can set agenda items for public debate, direct and orient political discussion, and contribute to impacting and molding legal norms and values. At the same time, there are cases that exemplify how international law, in particular international human rights law (and related fields such as international humanitarian law, international refugee law and international criminal law), may constitute a useful tool to resist oppressive regimes and unjust laws, policies or judicial decisions affecting those in a heightened condition of discrimination, vulnerability and exclusion, ${ }^{53}$ as will be shown below.

\section{A. Socio-economic precariousness}

Specifically in the context of socio-economic deprivation, Roberto Gargarella has studied the 'right to resistance' and has coined the term 'legal alienation', that is, when the whole of the normative system turns against the persons that constitute it. In such a situation the law starts to serve purposes contrary to those that justified its existence. He refers to contexts where peo-

52 For a detailed account, see ICNC, A Guide to Civil Resistance, op. cit.

53 See, e.g., FrISSO, G.M., «El derecho internacional penal como instrumento de resistencia en los tribunales populares: el Tribunal Internacional para la Justicia Restaurativa Aplicación en El Salvador», in Anuario Iberoamericano de Derecho Internacional Penal, vol. 4, 2016, on the use of international criminal law as a foundation and guideline for the actions of the International Tribunal for Restorative Justice in El Salvador, the civil society initiative of a people's tribunal to analyze grave human rights violations and crimes against humanity occurred in El Salvador. See also more generally ARTHUR, P., «How «transitions» reshaped human rights: a conceptual history of transitional justice», in 31 Human Rights Quarterly, 2009, pp. 321-367. 
ple are systematically deprived of shelter or home, suffer daily hunger, or are systematic victims of violence; that is, systems where people confront some of the worst grievances that a person can face..$^{54}$

In societies with larger inequality of properties, resources and income, such communities will be likely to have a less egalitarian allocation and distribution of power and, therefore, worse institutions, which tend to replicate and propagate the initial conditions. Indeed, as pointed out by Gillian $\mathrm{McNaughton,} \mathrm{'economic} \mathrm{and} \mathrm{social} \mathrm{inequality} \mathrm{have} \mathrm{an} \mathrm{impact} \mathrm{on} \mathrm{civil} \mathrm{and}$ political rights, including the rights to take part in the government'. As she observes, it is not simply that wealthy people are able to enjoy their human rights to a fuller extent than other people. The problem is that 'their wealth, power and influence actually diminish the power of others and their real opportunity to influence the policymaking institutions that have an impact on their lives'. ${ }^{55}$

Even more, if the apparatus of power allows abuses and oppression in a systematic way, there may be evidence of the existence of serious procedural deficiencies - deficiencies that are linked to the institutional system and that show that it is incapable of repairing the existing evils. Such deficiencies, which cause serious offenses by the State against the dignity of the person, 'allude to the defects of the judicial system, which seems unable to accommodate or satisfy the demands of the most (unprotected) groups, ensuring protection of their fundamental rights'. ${ }^{56}$ To this problem, authors like Luigi Ferrajoli have responded with proposals concerning the national level, by strengthening the guarantee mechanisms to make fundamental rights justiciable, through the independence of the Judicial Power, the autonomy of the magistrates and the expansion of the sphere of the undecidable, both in favor of the last minority (the individual), and to protect the less favored groups, typically excluded from the system. ${ }^{57}$

54 GaRgarella, R., «El derecho de resistencia en situaciones de carencia extrema», en Ch. CouRTIS (comp. ), Desde otra mirada, textos de teoría crítica del Derecho (2. ${ }^{a}$ ed.), Eudeba, Buenos Aires, 2009, p. 114 and following.

55 MacNaughton, G., «Beyond a Minimum Threshold: The Right to Social Equality», in MinKLER, L. (ed), The State of Economic and Social Human Rights: A Global Overview, Cambridge University Press, 2013, p. 290. See also by the same author «Untangling equality and non-discrimination to promote the right to health care for all», in Health and Human Rights Fournal, vol 11, No 2, 2009, available at http://www.hhrjournal.org/index.php/hhr/article/viewArticle/173/257

56 GARGARELLA, op. cit., p. 116.

57 Ferrajoli, L., La teoría del derecho en el paradigma constitucional, Cajica, Puebla, 2009. 
At the international level, efforts are being made to strengthen procedural guarantees against the abuses of public and also of private power, for instance, through the 'Zero draft (legally binding instrument to regulate, in international human rights law, the activities of transnational corporations and other business enterprises)', currently under negotiation by States under the auspices of the UN Human Rights Council, ${ }^{58}$ in great part due to the pressure of people's movements and civil society organizations.

While civil resistance may be deemed at first impression to focus mainly on civil and political rights, e.g., electoral liberties, freedom of expression, right to be protected from arbitrary detention; the fact is that economic, social and cultural rights (ESC Rights) are equally relevant in people's movements, which have often been directed to further economic equality and social justice goals. The equal importance of ESC Rights with regards to civil and political rights is also confirmed from an international law standpoint. By the adoption in 2008 and entry into force in 2013 of the Optional Protocol to the ICESCR, which includes an individual complaints mechanism regarding violations of ESC Rights, the equivalent hierarchy of ESC Rights is recognized and they are placed at the same level of international justiciability as civil and political rights, thus fulfilling the post-Cold War political affirmation of the Vienna Declaration of 1993 that 'all human rights are universal, indivisible and interdependent'. ${ }^{59}$

The Optional Protocol to the ICESCR also includes the mechanism of inquiry procedure which the UN Committee on ESC Rights, interpretative body of the ICESCR, may initiate upon receipt of reliable information on grave or systematic violations by a State party (article 11). Such procedure may offer advantages over individual communications for addressing situations of structural human rights violations, and as such it can open an avenue for civil resistance movements to use strategic litigation to further social justice goals.

At the regional level, despite the prevalence of global socio-economic deprivation and inequality, and increasing (though still not dominant) schol-

58 UN Human Rights Council, Open-ended intergovernmental working group on transnational corporations and other business enterprises with respect to human rights (OEIWG), 'Zero Draft' (legally binding instrument to regulate, in international human rights law, the activities of transnational corporations and other business enterprises) (16 July 2018) A/HRC/RES/26/9.

59 Article 5 of the Vienna Declaration and Program of Action, UN General Assembly, World Conference on Human Rights, A/CONF.157/23, 12 July 1993. 
arship addressing it, ${ }^{60}$ case-law in this area is scarce or is usually framed as a violation of civil and political rights (and not ESC Rights), and ordinarily not as a breach of equality.

In M.S.S. v. Belgium and Greece (2011), for instance, the European Court of Human Rights (ECHR) determined that the inhumane material conditions in which an Afghan asylum-seeker was living in Greece violated Article $3 \mathrm{ECoHR}$ (prohibition of torture and ill-treatment). In Yakye Axa v. Paraguay (2005) and Xákmok Kásek v. Paraguay (2010), concerning violations, among others, of ESC Rights affecting indigenous communities subject to structural discrimination, the Inter-American Court of Human Rights (IACHR) did not determine a violation of the right to equality before the law contained in Article 24 ACHR, although there were weighty reasons to do so. ${ }^{61}$

Existing violations of equality before the law through direct or indirect discrimination, and breaches to the right to equal protection of the law on the basis of poverty or economic status remain a matter open for further exploration in terms of human rights law and civil resistance as a possible conceptual and practical toolkit to tackle it.

\section{B. Undocumented migrants and other non-citizens}

While civil resistance scholarship has studied the links between people's movements and international law, for the most part it has not focused on migrants' rights or specifically undocumented migrants, ${ }^{62}$ and the reflections on

60 See, e.g., apart from the work by Roberto Gargarella quoted above, Courtis, C. (compilador), Ni un paso atrás: La probibici ón de regresividad en materia de derechos sociales, Editores Del Puerto, Buenos Aires, 2006; and ABRAmovich, V.; CourTis, C., Los derechos sociales como derechos exigibles (Prologue by Luigi Ferrajoli), Trotta, Spain, 2002; and Pogge, T., «Severe Poverty as a Human Rights Violation», in Pogge, T. (ed.), Freedom from Poverty as a Human Right: Who Owes What to the Very Poor (Oxford, Oxford University Press-United Nations Educational, Scientific and Cultural Organisation, 2007; and SALOMON, M.E., «International Human Rights Obligations in Context: Structural. Obstacles and the Demands of Global Justice», in Andreassen, B.A and Stephen, P.M. (eds), Development as a Human Right: Legal, Political and Economic Dimensions, 2nd edn (Antwerp, Intersentia, 2010) and by the same author, Global Responsibility for Human Rights: World Poverty and the Development of International Law (Oxford, Oxford University Press, 2007).

61 See, e.g., Valeska, M.; Contreras, D.; Trabucco Serán, A.K., «Dos concepciones de igualdad en el sistema interamericano de derechos humanos: una superposición que amenaza a las acciones afirmativas», Memoria de Grado (Facultad de Derecho, Universidad de Chile, 2009) 109-116.

62 However, see footnote 118 at p. 153 of Elizabeth A. Wilson's monograph, op. cit. 
irregular migration and social movements come mostly from the field of political science and international relations. ${ }^{63}$

Addressing the conditions of undocumented migrants at the global level, in its account of State obligations towards undocumented migrant domestic workers, especially women and children, the UN Committee on the Rights of Migrant Workers and Members of their Families (Committee on RMW), qualifies the vulnerabilities they face as 'extreme' and based on Article 69 of the International Convention on the Protection of the Rights of All Migrant Workers and Members of their Families (CRMW) calls for States to take appropriate measures to address such vulnerabilities and 'consider policies, including regularization programs, to avoid or resolve situations in which migrant domestic workers are undocumented or are at risk of falling into irregular status' ${ }^{64}$

The intersectional discrimination ${ }^{65}$ suffered as an undocumented migrant worker and as a woman, had also been signaled by the UN Committee on the Convention on the Elimination of All Forms of Discrimination Against Women (CEDAW) in its General Recommendation No 26 on Women Migrant Workers, of $2008 .{ }^{66}$

Generally speaking, the process of migration has been underlined in the last years from an international human rights perspective, although few works have done so in the fields of migration and gender, ${ }^{67}$ including feminist theory related to the heightened vulnerabilities faced by undocumented migrant women and girls, such as labour exploitation, sexual violence and trafficking. ${ }^{68}$

63 Córdoba González de Chávez, D., «(In)visibilidad y resistencia. Ciudadanías clandestinas y activismo migrante transnacional», in Relaciones Internacionales, No. 39, 2018, Universidad Autónoma de Madrid, pp. 205-226.

64 General Comment No 1, para 52.

65 On intersectional discrimination, see CRENSHAW, K., «Mapping the Margins: Intersectionality, Identity Politics, and Violence Against Women of Color», Stanford Law Review, 1991, 43. See also Hope, L., «Between Irua and 'Female Genital Mutilation': Feminist Human Rights Discourse and the Cultural Divide», Harvard Human Rights Fournal, 1, 1995, 8; and BANKS, T. L., «Toward a Global Critical Feminist Vision: Domestic Work and the Nanny Tax Debate», fournal of Gender Race \& Fustice 1, , 1999, 3, 1-44.

66 UN CEDAW Committee, General Recommendation No 26 on Women Migrant Workers, CEDAW/C/2009/WP.1/R, adopted on 5 December 2008, para. 2.

67 See, e.g., Edwards, A.; Ferstman, C. (eds.), Human Security and Non-Citizens: Law, Policy and International Affairs, Cambridge University Press, 2010; TruOnG, T-D., Gasper, D., HandMAKER, J., and BERGH, S.I. (eds), Migration, gender and social justice: perspectives on human security, Hexagon Series on Human and Environmental Security and Peace, vol. 9, 2014.

68 Truong, T-D.; Wieringa, S.; ChHachin, A. (eds.), Engendering Human Security. Feminist Perspectives, Women Unlimited, India/Zed Books Ltd., USA, 2006. 
Other research highlights the cooperative strategies and legal actions engaged in by social actors in defense of migrant women's rights (in some cases examined through the lens of international human rights law) in a similar perspective to that submitted in this article. Work by Tequila J. Brooks, for instance, discusses and compares the facts and claims raised in petitions by the Union for Agriculture Workers (UFCW) Canada and Centro de los Derechos del Migrante (CDM) Mexico, under applicable legal frameworks in Canada, the U.S., Mexico, and the North American Agreement on Labor Cooperation (NAALC), arguing that sex discrimination is pervasive in recruitment for professional visa programs as well as low wage visa programs. ${ }^{69}$ These publications, though, refer to documented (and not undocumented) women migrant workers and, at the same time, do not analyse such actions as possible forms of civil resistance.

Some illustrative human rights legal instruments and interpretations concerning the rights of persons in situation of vulnerability and social exclusion, particularly undocumented migrants, are useful to spells out their normative and interpretative implications, and to explores the conceptual and practical value of using this international legal framework as a basis for civil resistance to unjust migratory norms and policies.

Frequently such norms exceed the realm of migration law as such, and they are included as well in provisions in the areas of administrative and criminal law, i.e., the penalization of the actions of giving financial, transportation, or cooperation assistance to migrants, allowing them to rent an apartment, or providing them with medical care, as such materializing a legal tendency to 'criminalize human kindness', as put by Marie-Benedicte Dembour. ${ }^{70}$ An illustrative example is the situation recently faced by the crew of the ship of the Spanish NGO Proactiva Open Arms after it refused to hand over rescued migrants to the Libyan coast guard in international waters and, as a result, having their boat impounded by a Sicilian prosecutor who also threatened to charge them with criminal association. ${ }^{71}$

69 Brooks, T-J., «Sexism and Gender Stereotyping in International Guest Worker Programs: An Analysis of Two 2016 Petitions Filed Under the North American Agreement on Labor Cooperation», in Employee Rights and Employment Policy 7., vol. 22, No. 1, 2018; Dean Rusk International Center Research Paper; available at SSRN: https://ssrn.com/abstract=3195556 (last accessed 05/09/2018).

70 Presentation of Marie-Benedicte Dembour in the Conference 'Access Denied', organised by VU University Amsterdam, March 2012; personal notes taken.

71 See, e.g., Refugees Deeply, 'NGO Rescue Ship Seized by Italy After Standoff With Libyan Coast Guard', in News Deeply-Refugees Deeply, 20 March 2018, at https://www.newsdeeply. com/refugees/executive-summaries/2018/03/20 
International human right law does offer some promising answers and interpretations. To mention but some of the most representative ones, consider at the UN level the understanding of discrimination as covering distinctions on the basis of immigration status, and in relation to refugee status, asylum, nationality and statelessness of women, as pointed out by the CEDAW Committee. $^{72}$

Let us recall that undocumented migrants are usually termed as 'economic migrants' escaping poverty and deprivation, differencing them from refugees escaping persecution and armed conflict. ${ }^{73}$ Let us bear in mind, though, that people seeking 'asylum' or 'refuge', are requesting or in need of, precisely the proper 'documents' where they are recognized the status of 'refugees'. As such, many undocumented migrants -insofar as their situation is dependent on the granting (or not) of official State 'documents'- are asylum seekers or potential refugees expectant of a recognition or regularization of their condition. That being said, the specific legal figure of 'refugee', distinct from that of 'undocumented migrant' or other 'non-citizens', merits attention. The current humanitarian crisis experienced by persons fleeing mainly from Syria, but also from Lybia, Iraq and Afghanistan, gives an additional reason to consider the particular vulnerability of refugees.

A recent interpretation of the UN Convention on the Elimination of Discrimination Against Women (CEDAW), provided by the UN CEDAW Committee in 2014, suggests a further enhancement of the applicability of the non-refoulment obligation -that is, of the obligation not to return a person to a country where she or he may risk death, persecution, torture or unlaw-

72 See CEDAW Committee, General recommendation No. 32 on the gender-related dimensions of refugee status, asylum, nationality and statelessness of women, CEDAW/C/GC/32, 14 November 2014, paras. 7 and 8 .

73 The 1951 Convention on the Status of Refugees and its 1967 Protocol, define a refugee as a person who is outside his or her country of nationality or habitual residence; has a well-founded fear of being persecuted because of his or her race, religion, nationality, membership of a particular social group or political opinion; and is unable or unwilling to avail him or herself of the protection of that country, or to return there, for fear of persecution; see Article 1A(2) of the Convention relating to the Status of Refugees, adopted on 28 July 1951 by the UN Conference of Plenipotentiaries on the Status of Refugees and Stateless Persons convened under General Assembly Resolution 429 (V), and entered into force on 22 April 1954. See also Protocol on the Status of Refugees, approved in New York on 31 January 1967 and entered into force on 4 October 1967, in conformity with Article VIII. The Protocol opens up the definition of refugee of the 1951 Convention to universal application, by suppressing the reliance on occurrences having happened before 1 January 1951 and by eliminating any geographic limitation in the applicability of the 1951 Convention (given the 1951 definition is confined only to Europe). 
ful deprivation of liberty-, to cover cases of 'serious forms of discrimination against women, including gender-based violence'. ${ }^{74}$

The 'legal limbo' affecting undocumented migrants, particularly women, in turn places them in an exposed position to labor exploitation, abuse and violence, with the differentiated gender dimension this involves. As many of the rest of the so called 'low-skilled' migrants, as well as the broad category of undocumented migrants, most women leave a State where they experience poverty and exclusion, to move within a market that wants and needs migrants, but doesn't welcome them, in turn facing a State that offers few avenues to defend, protect and guarantee their rights.

Other civil society organizations have also documented the effects of the lack of access to justice of undocumented women abused and living in EU countries. ${ }^{75}$ Indeed, undocumented women are particularly vulnerable. Unauthorized stay in several EU countries is a criminal offence and police are required to report anyone who they suspect is in the country illegally to immigration authorities, such as in Belgium, for example. Women who do come forward have few avenues to obtaining legal status, especially if they do not have children. Other women endure years of abuse at the hands of their partner, coming forward only when they obtain permanent residence through their children: only when they 'have papers' ${ }^{76}$

The way legal irregularity interacts with the susceptibility of migrant women and of female migrant workers as exposed in the analyzed sources, allows for a deeper understanding of the 'constructed vulnerability' of these women. ${ }^{77}$ When confronted with the violation of a particular human right,

74 See UN CEDAW Committee, General recommendation no. 32 on the gender-related dimensions of refugee status, asylum, nationality and statelessness of women, CEDAW/C/GC/32, 14 November 2014, para. 22. See also article 33 of the 1951 Convention on the Status of Refugees on the right to non-refoulment.

75 See Human Rights Watch (HRW), «Belgium: Abused Migrant Women Fear Deportation. Legal Loopholes, Inadequate Shelter Access Send Women Back to Abusers», 8 November 2012, available at www.hrw.org/news/2012/11/08/belgium-abused-migrant-women-fear-deportation.

76 HRW, «The Law was Against Me», ibid, Executive Summary. See also the web-documentary by PICUM www.undocumentary.org for accounts on immigration legislation in several European countries.

77 On the role of the State in constructing vulnerability, see ANDERSON, B., «Mobilizing Migrants, Making Citizens: Migrant Domestic Workers as Political Agents», Etbnic and Racial Studies 1, 69, 2010, 33. See also SCRINZI, F., «The Globalisation of Domestic Work: Women Migrants and Neodomesticity», in FreEdMAN, J. (ed), Gender and Insecurity: Migrant Women in Europe (Aldershot, Ashgate, 2003) 77-90. 
undocumented migrants, and especially women and girls within this group, are unable or unwilling to turn to the institutional mechanisms in seeking redress for such violation.

At the regional levels, Advisory Opinion AO 18/03 of the IACHR, emphasized that 'States may not subordinate or condition observance of the principle of equality before the law and non-discrimination to achieving their public policy goals, whatever these may be, including those of a migratory character', ${ }^{78}$ a progressive stance confirmed in subsequent judicial cases. ${ }^{79}$

In the realm of the Council of Europe, the ECHR has decided some important cases on the rights of undocumented migrants and other non-status persons, although it has missed the chance of establishing a clear and firm interpretation on the scope of State obligations in the context of border control, as well as the rights of gravely ill migrants..$^{80}$ Recent developments, though, suggest promising horizons. In a highly significant judgment handed down on 30 March 2017, the ECHR held unanimously that there had been a violation of Article 4 (prohibition of forced labor) of the European Convention on $\mathrm{Hu}-$ man Rights in a case concerning 42 Bangladeshi nationals who did not have work permits and were subjected to forced labor. In the case of Chowdury and Others $v$ Greece, the question for the Court was whether someone with freedom of movement could be said to be trafficked and/or subjected to forced labor. The ECHR also importantly went on to consider the scope and ambit of Article 4 stating that protection measures include identification of victims and provisions for their recovery. The employers of the Bangladeshi nationals had recruited them to pick strawberries on a farm in Manolada (Greece) but failed to pay the applicants' wages and obliged them to work in difficult

78 IACHR, AO 18/03, September 2003, concluding para. 11. For argumentation see para. 172.

79 See, e.g., Case of The Yean and Bosico Children v. Dominican Republic, Judgment of September 8, 2005; Case of Nadege Dorzema et.al. v. Dominican Republic, Sentence of 24 October 2012; Case of Expelled Dominican and Haitian Persons v. Dominican Republic, 28 August 2014.

80 In this line, see, e.g., cases by the ECHR, Saadi v. United Kingdom, Appl. no. 13229/03, 29 January 2008; Nv United Kingdom, Appl No 26565/05, 27 May 2008 on an HIV-affected woman of Ugandan origin residing irregularly in the UK and at risk of expulsion, although the Court had previously ruled in favour of the applicant in the similar case of $D v$ the United Kingdom, Appl No 30240/96, 2 May 1997 (as also noted in the Joint Dissenting Opinion of Judges Tulkens, Bonello and Spielmann in the case of $N v U K$, in which the Dissenting Judges thought the Court should have also ruled in favour of $N$ as it did in favour of $D v U K)$. See also GANTY, S., «S.F. v. Belgium: missed opportunity to fairly protect seriously ill migrants facing expulsion», Strasbourg Observers Blog, April 30, 2015, available at https://strasbourgobservers.com/2015/04/30/s-j-vbelgium-missed-opportunity-to-fairly-protect-seriously-ill-migrants-facing-expulsion/ 
physical conditions under the supervision of armed guards. The Court found, firstly, that the applicants' situation was one of human trafficking and forced labor, and specified that exploitation through labor was one aspect of trafficking in human beings. The Court then held that the Greek state had failed in its obligations to prevent the situation of human trafficking, to protect the victims, to conduct an effective investigation into the offences committed and to punish those responsible for the trafficking. ${ }^{81}$

The ECHR also decided in 2017 the landmark case of N.D. and N.T, v. Spain in which it determined that the immediate return ('push-back' or 'devolución en caliente') to Morocco of sub-Saharan migrants who were attempting to enter Spanish territory in the North-African enclave of Melilla amounted to a collective expulsion of foreign nationals, in breach of the Convention (art. 4 of Protocol No. 4 prohibiting collective expulsions together with Article 13 on right to an effective remedy). ${ }^{82}$ The implications of this type of cases for equality rights could be spelled out more clearly and developed in scholarship and future human rights cases. These judgments open new avenues for reflection in the years to come regarding the conditions of undocumented migrant workers and their families in contemporary Europe and worldwide, and how to tackle unjust conditions through people's movements.

Due to the clandestinity derived from their irregular legal status, undocumented migrants fear denial of their rights or deportation if they dare come forward, or they often face serious substantive or procedural obstacles when they do. This violation of both a certain human right and of their right to access to justice, translates into a double victimization and calls for civil resistance actions that can raise the voice for people in an irregular migratory situation who may not or do not wish to do so, and at the same time try to enhance agency of migrants themselves to organize and claim their universally recognized rights.

\section{Gender inequality and violence against women}

While feminist movements have been extensively studied, including in social action in Latin America, as the ICNC's A Guide to Civil Resistance

81 See ECHR, Chowdury and Others v Greece, Appl. 21884/15, 30 March 2017 (available in French). 82 N.D. and N.T, v. Spain, Applications nos. 8675/15 and 8697/15, judgement of 10 March 2017. 
gives evidence to ${ }^{83}$ the literature on migrant women and specifically undocumented migrant women and their ties to social mobilization, remains scarce. $^{84}$

Let us recall that discrimination based on gender, and more specifically violence against women as a form of discrimination, has been recognized by international human rights law as a breach to equality, ${ }^{85}$ although it remains widespread globally. Still, the theoretical and practical relevance of eliminating violence against women as a human rights issue and a matter of justice is (arguably) accepted more readily and broadly by national governments and by international and regional governance than that of undocumented migration.

In terms of conceiving violence against women as a matter of discrimination and a breach to equality, representative case-law includes Opuz v. Turkey (2009), ${ }^{86}$ and Eremia and Others v. Moldova (2013), ${ }^{87}$ both by the ECtHR, which determined that domestic violence and lack of proper investigation and protection by authorities involved a violation of Art. 2 (right to life), in the first case, and of Article 3 (prohibition of torture and inhuman or degrading treatment or punishment) in both cases, as well as a violation of Article 14 due to a violation of equal protection of the law. In Cotton Field v. Mexico, of 2009, concerning the abduction and disappearance of a woman and two girls, who were later found to have been subjected to sexual violence and killed, the IACHR determined a violation to Article 1 ACHR (non-discrimination), among others, in that the State knew of the risk of this occurring due to the context of structural discrimination againts women and thus it held a particularly strong obligation to prevent and eradicate these forms of gender-based violence. ${ }^{88}$

Two cases in the African context are worth mentioning: the case of EIPR and Interights v. Egypt, resolved in 2011, involved violent attacks against four female journalists covering a political demonstration of the Egyptian Move-

83 See particularly CHAPTER F., «Feminist Movements and Protests», in vol. 2, available at https:// civilresistance.info/bibliography. See also regarding the struggle for women's rights, BEYERLE, S., «Courage, Creativity, and Capacity in Iran: Mobilizing for Women's Rights and Gender Equality», in Georgetown fournal of International Affairs, 9, 2008, pp. 41-49.

84 In this field, see, e.g., ERTEKIN, C., «Non-status women of Montreal demand justice», McGill Daily, 18 January 2016, available at http://www.mcgilldaily.com/2016/01/non-status-women-of-montreal-demand-regularization/ (last accessed 5 September 2018).

85 See, e.g., CEDAW, General recommendation No. 35 on gender-based violence against women, updating general recommendation No. 19, CEDAW/C/GC/35, 14 July 2017.

86 ECHR, Opuz v. Turkey, Appl. No. 33401/02, 9 June 2009.

87 ECHR, Eremia and Others v. Moldova, Appl. No. 3564/11, 28 May 2013.

88 IACHR, González et al. v. Mexico ('Cotton Field' v. México), Judgement of 16 November 2009. 
ment for Change (Kefaya) which were ordered and condoned by police officers. ${ }^{89}$ The case of Equality Now and EWLA v. Ethiopia, resolved in 2016, concerned the abduction, rape and forced marriage of a 13-year-old girl, which was judicially condoned by relevant authorities. ${ }^{90}$ Notably, in both cases, the African Commission on Human and Peoples' Rights specifically framed the matter as a violation of Article 3 (right to equality before the law and equal protection of the law), among others, for the failure of Egypt and Ethiopia to adequately prevent and protect the victims from these situations of violence.

Let us recall that on the basis of the 'International Bill of Rights', the Convention on the Elimination of All Forms of Discrimination against Women (CEDAW), adopted in 1979 as an instrument of non-discrimination, also specifically includes in its Art. 2.c) and d) the right of women to equal protection of the law, thus addressing one of the most widespread forms of discrimination, at that time and in the present, namely, legal and institutional discrimination which continues to give rise to gender inequality.

Already since 1990 Matthew Lippman wrote 'In an era in which States have disregarded the requirements of international law, it is hypocritical to deny protection to those who are acting in the nature of private attorneys general to vindicate human rights'. While we have advanced importantly since then, we currently see as well threats to hard-gained and legally recognized rights. In this context, let us reflect with Lippman, that 'the recognition of a domestic and international right of civil resistance in defense of human rights is an important step in the creation of a vigorous citizenry. No State has the prerogative to punish those who act in a nonviolent, proportionate fashion to protect the inherent and inalienable rights of any members of the human family'. ${ }^{1}$

\section{SOME CONCLUSIONS}

Civil resistance may be grounded in general principles of law, concretely in general human rights principles, insofar as such people's movements align with human rights values and norms.

\footnotetext{
89 African Commission on Human and Peoples' Rights, Egyptian Initiative for Personal Rights and INTERIGHTS v Egypt, Communication 323/06, 2011.

90 Equality Now and Ethiopian Women Lawyers Association (EWLA) v. Ethiopia, Communication 341/2007, 2015.

91 Lippman, M., op. cit., pp. 372-373.
} 
The reviewed scholarship on civil resistance reveals that people's movements have increased exponentially in recent years and remain a social resource of protest and claim of rights, even in Constitutional liberal democracies, at the national and international levels of action. Thus, the relationship of civil resistance to international law constitutes an obliged source of reflection for international legal scholars and practitioners.

From the analyzed academic sources and the international law basis founded on general principles of human rights, some of the extremes that would allow for -and even require- civil resistance in our current scenario, seem to meet the threshold of gravity and pervasiveness that could justify people's movements.

Such resistance is not only founded in the concept and even the effectiveness of people's movements, but it can also be legitimized in terms of international human rights law and the interpretations given by human rights judicial and quasi-judicial bodies at the UN and regional levels.

People in conditions of poverty and social marginalization, as well as undocumented migrants and other non-citizens such as asylum-seekers and refugees, and women experiencing gender inequality, particularly violence, face grave vulnerability, discrimination and injustice in our world today. These factual situations are at times coupled with ever more rigid, exclusionary and criminalizing norms and policies. The empirical realities of constant risks and lack of access to justice faced by these persons, together with existing legal gaps, place them in conditions of heightened vulnerability to different forms of abuse and violence - thus defining the contour of a situation requiring responsible defiance under the civil resistance conception understood as cooperative nonviolent collective action.

It has been argued, on the one hand, that assuring the principle of universality of all human rights for all persons, is one of the most challenging situations for contemporary public international law. As such, actions of civil resistance may constitute a useful avenue to uphold their human rights, particularly in our technological era where well-founded demands and new forms of protest and struggle through social networks and platforms, can find a way to echo, replicate and generate political impact.

On the other hand, and more importantly for civil society actors and the very people affected by poverty, inequality and exclusion, the actions of civil resistance to unjust norms, policies and even judicial decisions, find in international human rights law a legal foundation and source of justification.

Indeed, as reviewed in the previous sections, UN and regional human rights bodies provide us with legally-substantiated arguments and interpreta- 
tions that allow us to construct a civil resistance toolkit to legitimize actions of political defiance and of defense of the human rights of people in conditions of vulnerability. Human rights law and the values that sustain it, oblige the State to prioritize the protection of the human rights of those most vulnerable including that of access to justice.

The grounding of civil resistance in international human rights law becomes more relevant in the face of increasing immigration restrictions based on immigration status or gender, and more indirectly on socio-economic condition, that not only leave whole sectors of the population at the margin of the law or invisible to the law, but that also depict many of the rest of individuals and social actors engaging with them, as persons acting against the law.

Contrary to this view, international law and doctrine, and more particularly human rights general principles and specific provisions, may provide a solid normative foundation, an operational language and an institutional setting for civil resistance. This article has sustained the idea that such a foundation may better aid persons and organizations carrying out actions of resistance and working every day to uphold the human dignity of people in vulnerable conditions as an imperative of justice and as an exigence of law. 
